\title{
Discrimination of the Stock Complex of Atlantic Cod (Gadus morhua) off Southern Labrador and Eastern Newfoundland, as Inferred from Tagging Studies
}

\author{
W. H. Lear \\ Fisheries Research Branch, Department of Fisheries and Oceans \\ Northwest Atlantic Fisheries Centre, P. O. Box 5667 \\ St. John's, Newfoundland, Canada A1C $5 \times 1$
}

\begin{abstract}
During February-March 1978-81, about 25,000 Atlantic cod $\geqslant 45 \mathrm{~cm}$ ) were tagged from the prespawning concentrations on Hamilton Bank. Belle Isle Bank, Funk Island Bank and northern Grand Bank. There is evidence of a consistent annual pattern of migration to inshore waters during summer and to offshore areas during winter for each group of cod tagged along the outer continental shelf. The Hamilton Bank component evidently contributes to the southern Labrador and northeast Newfoundland coastal fisheries mainly from Notre Dame Bay northward. The Belle Isle Bank component migrates during summer mainly to southern Labrador, Strait of Belle Isle entrance and northeastern Newfoundland as far south as Notre Dame Bay. The pattern of movement is similar to that of the Hamilton Bank component except for a greater proportion in the Strait of Belle Isle. Cod on the northern and northeastern slopes of Funk Island Bank migrate during summer to eastern and southeastern Newfoundland, with smaller proportions going to southern Labrador and the Strait of Belle Isle than from the taggings on Belle Isle Bank. Cod from the southwestern slope of Funk Island Bank contribute mainly to the summer inshore fishery of Notre Dame Bay and Bonavista Bay and in a smaller degree to the fishery in Trinity Bay, Conception Bay and the eastern part of the Avalon Peninsula. Cod which overwinter on northern Grand Bank migrate southwards across the bank to the Virgin Rocks and to the eastern slope of the bank. This component contributes mainly to the inshore fishery from Trinity Bay southward to St. Mary's Bay, with little effect on the fishery north of Cape Bonavista.
\end{abstract}

The evidence from tagging on winter concentrations is that each component contributes to the inshore fishery in specific, although wide, overlapping areas. Excessive exploitation of any one component of the stock complex could have adverse effects on the inshore fishery in the areas frequented by the summer migrants. It is desirable, therefore that the offshore fishery in winter should be managed so that the inshore fishery in summer and autumn would not be affected detrimentally by excessive exploitation of a particular component of the stock complex in Div. 2J, 3K and 3L.

\section{Introduction}

The cod populations off southern Labrador and eastern Newfoundland have been managed as a single stock complex since the implementation of total allowable catches in 1973 (ICNAF, 1972). There is a cline from north to south in such biological parameters as growth (May et al., 1965), fecundity (May, 1967), vertebral numbers (Templeman, 1981), and age and size at maturity (Fleming, 1960). At the same time, however, tagging studies have confirmed that there is clear indication of localization of tag recoveries in coastal waters of Labrador and Newfoundland from cod tagged at specific inshore and offshore localities (Templeman, 1979).

May (MS 1966) hypothesized that the cod stock complex was composed of at least three major groups, the distributions of which overlap in summer and tend to be separate in winter. These are as follows:

1. The "Labrador-Newfoundland" stock, which spawns mainly on Hamilton Bank and possibly to a small extent on the Northeast Newfoundland Shelf and is distributed in summer along the coasts of Labrador and northeastern Newfoundland.
2. The "Northeast Newfoundland" stock, which spawns mainly on Hamilton Bank but also on the Northeast Newfoundland Shelf. Its distribution in summer extends only along northeastern and eastern Newfoundland. Alternately, two stocks may be involved, one spawning on Hamilton Bank and the other on the Northeast Newfoundland Shelf.

3. "East Newfoundland" stock which spawns on the northern Grand Bank and is distributed in summer mainly along eastern Newfoundland but may extend to northeastern Newfoundland.

Templeman $(1962,1966,1974,1979,1981)$ and May (MS 1966) suggested that there is some evidence of smaller local stocks which are associated with shelf areas such as those off Baccalieu Island, Cape Bonavista, Fogo Island, Cape St. John, and Grey Islands to St. Anthony. Templeman (1979), from the results of taggings in 1962-66, reported that there was considerable homing of local populations of cod to original inshore tagging locations along the coast from Avalon Peninsula to northern Labrador. Either the fish remained in those coastal areas throughout the year or they actually "homed" to the areas to which they had 


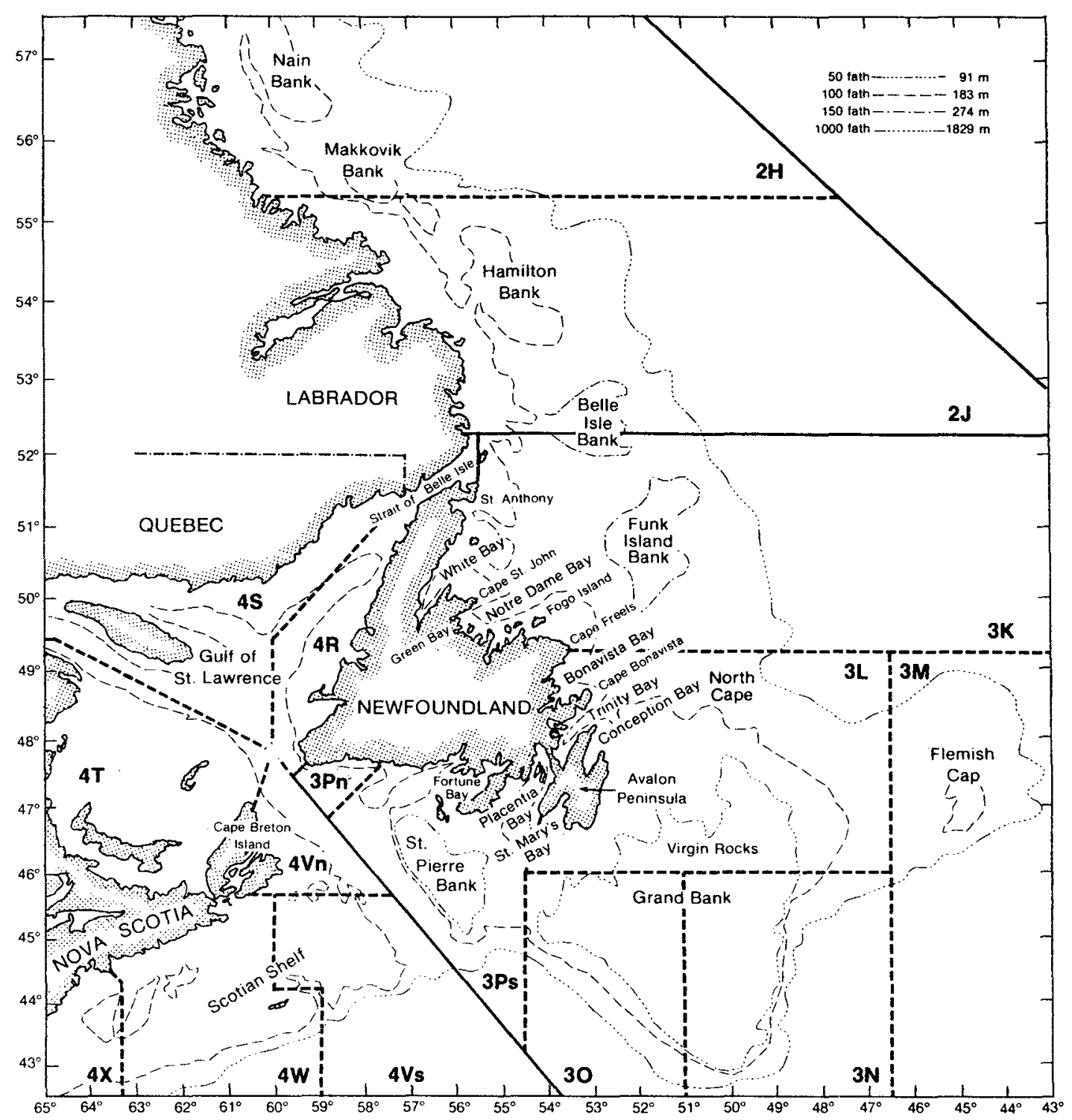

Fig. 1. Map showing the NAFO divisions and place names mentioned in the text.

drifted as larvae and in which they had spent the first years of their life as juveniles. The purpose of this paper is to reexamine migration patterns and stock relationships of cod off southern Labrador and eastern Newfoundland (Fig. 1) on the basis of recaptures of adults which were tagged offshore in areas of overwintering concentrations. May's (MS 1966) classification of the "stock complex" is discussed in the light of these more recent tagging studies.

\section{Materials and Methods}

During February-March of 1978-81, about 25,000 $\operatorname{cod}(\geqslant 45 \mathrm{~cm}$ ) were tagged off southern Labrador (Div. $2 \mathrm{~J}$ ) and eastern Newfoundland (Div. 3K and 3L), using Petersen disc, spaghetti T-bar and dangler tags (Table
1). The tag types were applied to cod in equal batches (50), so that any bias due to variation in tag loss among the different types would be equally distributed throughout all experiments. The taggings were conducted in winter on prespawning concentrations of cod on Hamilton Bank in 1981, Belle Isle Bank in 1978, Funk Island Bank in 1978-81, and northern Grand Bank in 1980.

The cod were caught in an Engels high-rise otter trawl (without small-mesh codend liner except in 1978), which was towed on bottom generally for 10-20 $\mathrm{min}$ and occasionally for $30 \mathrm{~min}$, depending on the density of cod deduced from echo-sounding. Because the concentrations of cod occurred in ice-covered areas at depths of $230-350 \mathrm{~m}$, the trawl was retrieved very slowly $(8-10 \mathrm{~m} / \mathrm{min})$ to allow the fish to acclimate 
TABLE 1. Tag types applied to cod during tagging operations of southern Labrador and eastern Newfouncland in the winters of 1978-81.

\begin{tabular}{|c|c|}
\hline Year & Tag type \\
\hline $1978-81$ & $\begin{array}{l}\text { Yellow Petersen disc and blank ( } 13 \mathrm{~mm} \text { diam.) at- } \\
\text { tached through the flesh posterior to first dorsal fin } \\
\text { with soft stainless steel wire allowing } 3 \mathrm{~mm} \text { space on } \\
\text { each side of fish. }\end{array}$ \\
\hline 1978 & $\begin{array}{l}\text { Yellow spaghetti T-bar }(7 \mathrm{~cm} \text { long }) \text { inserted at base of } \\
\text { first dorsal fin. }\end{array}$ \\
\hline \multirow[t]{3}{*}{$1979-81$} & $\begin{array}{l}\text { Yellow spaghetti T-bar }(8.25 \mathrm{~cm} \text { long }) \text { inserted at } \\
\text { base of first dorsal fin. }\end{array}$ \\
\hline & $\begin{array}{l}\text { Orange spaghetti T-bar }(8.25 \mathrm{~cm} \text { long) inserted at } \\
\text { base of first dorsal fin. }\end{array}$ \\
\hline & $\begin{array}{l}\text { Combination tag composed of yellow Petersen disc } \\
\text { and blank ( } 13 \mathrm{~cm} \text { diam.) attached through the flesh at } \\
\text { base of first dorsal fin allowing } 3 \mathrm{~mm} \text { space on each } \\
\text { side of fish, with yeliow dangler }(50 \times 13 \mathrm{~mm}) \text { at- } \\
\text { ched to trail along each side of fish. }\end{array}$ \\
\hline
\end{tabular}

to the changing pressure and to prevent suffocation from crowding in the codend. Also, the codend had to be retrieved in open water to prevent death of the cod from supercooling and eventual freezing. This occurred if, after being pulled through water where temperatures were $-1.5^{\circ}$ to $-1.7^{\circ} \mathrm{C}$, the cod were hauled through surface water filled with ice crystals. Similarly, the tagged cod were released in open water areas.

Tags were applied only to those cod which were classified as being in excellent condition. Any fish, with signs of bruising, scale loss, injury to fins and gills, bleeding, "pop-eye" condition, and distended swimbladder were routinely discarded during the tagging operations. The cod were released from the codend into holding tanks with running sea water. They were retrieved individually with dipnets, measured to the nearest centimeter (fork length), examined for the gill parasite Lernaeocera branchialis, tagged and placed in recovery tanks filled with running sea water. When it appeared that the fish had fully recovered from the shock of being handled and tagged (swimming actively), they were released through a hatch at the water line of the ship (i.e. they were placed, not dropped, into the sea).

Tag recoveries were grouped arbitrarily by seasonal periods, corresponding approximately to the offshore winter fishery (January-April) and the inshore summer and autumn fishery (May-December), and, where possible, by standard unit areas within the larger NAFO divisions. Generally, the information provided by fishermen or obtained from logbook records and observer reports was sufficient to determine the approximate locations of recaptures. There were a few instances $(<5 \%$ of offshore recaptures) where the tag recoveries could be assigned only to NAFO divisions, and these are not included in this analysis of the data by unit area.

The monthly nominal catches of cod by Newfoundland-Labrador fishermen in the designated unit areas, as collected and compiled by the Statistics Branch of the Department of Fisheries and Oceans, were combined for the two seasonal periods (see Appendix) and used to calculate the numbers of tags recovered by Newfoundland-Labrador fishermen per 1,000 tons of cod caught. It was not possible to include the tags recovered offshore by non-Canadian fishermen, because their catches were not available by unit areas. However, the overall distributions of tag recoveries by Canadian and non-Canadian fishermen are illustrated in the diagrams by season and unit area. The adjusted recovery rates, based on tag recoveries and catches by Newfoundland-Labrador fishermen, are considered to be representative of the overall situation, because tag recoveries by these fishermen accounted for about $56 \%$ of all tags returned during the JanuaryApril period, $90 \%$ of all tags returned during the MayDecember period, and $83 \%$ of all taşs returned during 1978-82 (Table 2).

\section{Results}

\section{Northeastern Hamilton Bank (Fig. 2)}

From 3,305 cod tagged on northeastern slope of Hamilton Bank during 18-22 March 1981, there were

TABLE 2. Summary of information on cod tagging experiments off Labrador and eastern Newfoundland in February-March, 1978-81, and recoveries to the end of 1982. (Numbers in parentheses are tag recoveries by Newfoundland-Labrador fishermen.)

\begin{tabular}{|c|c|c|c|c|c|}
\hline Tagging area & $\begin{array}{l}\text { Tagging } \\
\text { year }\end{array}$ & $\begin{array}{l}\text { Tagging } \\
\text { dates }\end{array}$ & $\begin{array}{l}\text { Number } \\
\text { tagged }\end{array}$ & $\begin{array}{l}\text { No. of tag } \\
\text { recoveries }\end{array}$ & $\begin{array}{l}\text { Fig. } \\
\text { ref. }\end{array}$ \\
\hline NE Hamilton Bank & 1981 & 18-22 Mar & 3,305 & $290(228)$ & 2 \\
\hline Belle isle Bank & 1978 & 26 Feb-12 Mar & 2,728 & $450(366)$ & 3 \\
\hline N Funk island Bank & 1978 & $27 \mathrm{Feb}-10 \mathrm{Mar}$ & 1,725 & $241(195)$ & 4 \\
\hline N Funk Island Bank & 1979 & 27 Feb-2 Mar & 3,119 & $348(274)$ & 5 \\
\hline N Funk Island Bank & 1981 & 25-27 Mar & 3.139 & $284(245)$ & 6 \\
\hline E Funk Island Bank & 1979 & $25 \mathrm{Feb}-2 \mathrm{Mar}$ & 1,801 & $285(232)$ & 7 \\
\hline SE Funk Island Bank & 1980 & 17-23 Mar & 2,259 & $133(112)$ & 8 \\
\hline W Funk Island Bank & 1980 & 24-27 Mar & 2,158 & $362(340)$ & 9 \\
\hline SW Funk Island Bank & 1981 & 14-17 Mar & 1,195 & $141(137)$ & 10 \\
\hline N Cape of Grand Bank & 1980 & $28-30 \mathrm{Mar}$ & 1.978 & $157(110)$ & 11 \\
\hline
\end{tabular}



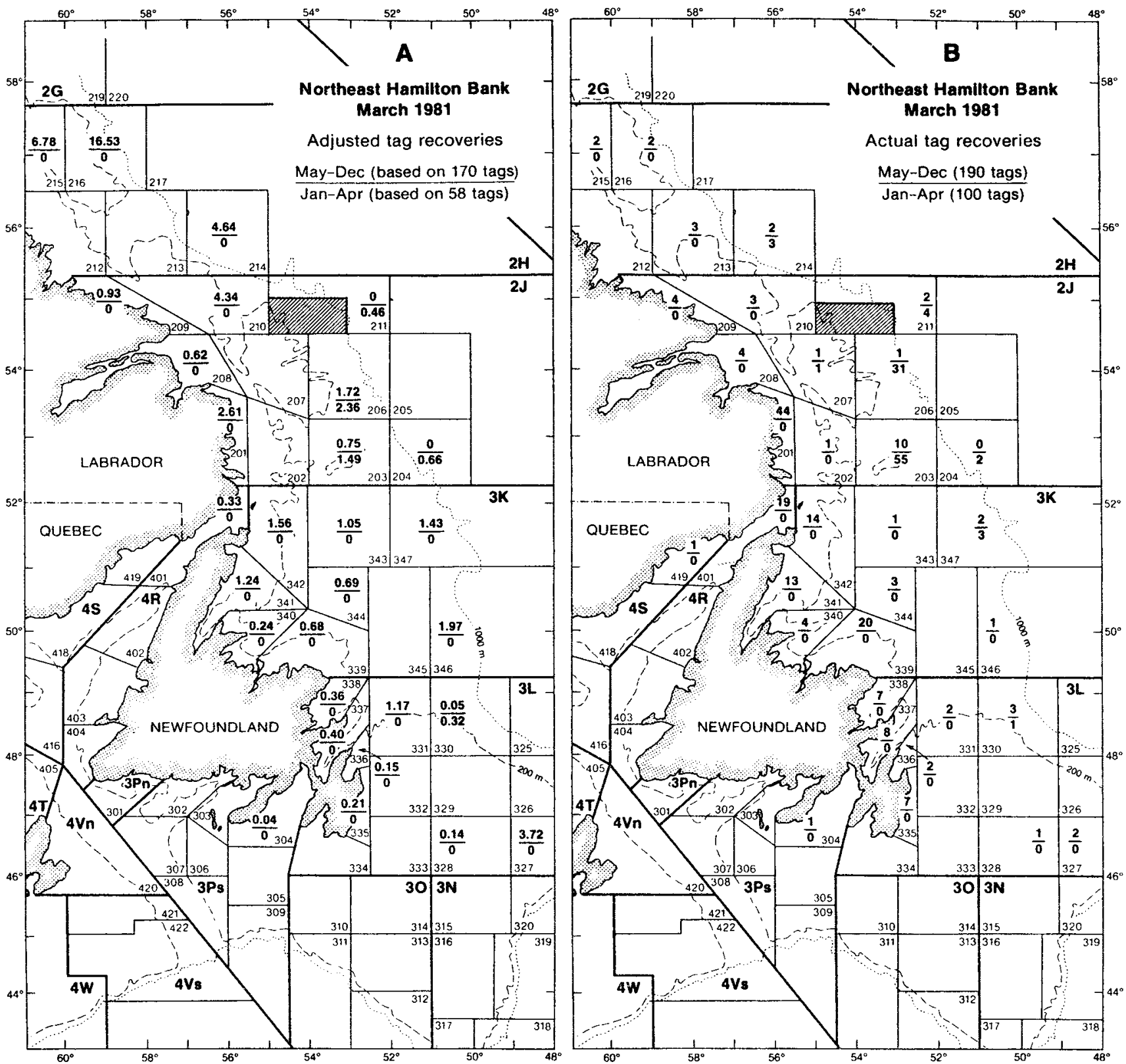

Fig. 2. Distribution of (A) adjusted tag recoveries by Newfoundland-Labrador fishermen and (B) actual tag recoveries by all fishermen, from cod tagged on northeastern Hamilton Bank in March 1981.

190 recoveries during the two ensuing May-December periods, of which 170 were reported by NewfoundlandLabrador fishermen. Inshore recoveries (adjusted to numbers per 1,000 tons of cod caught) were highest in the southern Labrador, St. Anthony and White Bay areas (Fig. 2A), with declining prevalence southward to the Avalon Peninsula. About $78 \%$ of the adjusted recoveries from inshore areas occurred north of Cape Freels (Table 3 ). Recovery rates were quite high in some offshore unit areas, particularly off Labrador and on the eastern Grand Bank, but these rates are based on just 1 or 2 tag recoveries in each area (Fig. 2B). Only 8 tags were recovered on the Grand Bank (Div. $3 L$ ), and
1 was reported from Placentia Bay. These movements confirm that cod which overwinter on the northeastern slope of Hamilton Bank contribute substantially to the inshore fishery of southern Labrador and northeastern Newfoundland north of Cape Freels and to a lesser degree in areas from Bonavista Bay southward. A few of these tags were recovered in the Strait of Belle Isle, indicating some intermingling with the northern Gulf of St. Lawrence stock.

During the January-April period, the highest numbers and adjusted rates of tag recoveries occurred on the southeastern slope of Hamilton Bank, adjacent 
TASLE 3. Percentage distribution of adjusted tag recoveries in inshore areas of Labrador and eastern Newfoundland during the May-December periods to the end of 1982 from 11 tagging operations in offshore areas during the winters of $1978-81$.

\begin{tabular}{|c|c|c|c|c|c|c|c|c|c|c|}
\hline $\begin{array}{c}\text { Recovery } \\
\text { areas }\end{array}$ & $\begin{array}{c}\text { Northeast } \\
\text { Hamilton } \\
\text { Bank } \\
(1981)\end{array}$ & $\begin{array}{c}\text { Belle } \\
\text { Isle } \\
\text { Bank } \\
(1978)\end{array}$ & $\begin{array}{c}\text { Northern } \\
\text { Funk I. } \\
\text { Bank } \\
(1978)\end{array}$ & $\begin{array}{c}\text { Northern } \\
\text { Funk 1. } \\
\text { Bank } \\
(1979)\end{array}$ & $\begin{array}{l}\text { Northern } \\
\text { Funk I. } \\
\text { Bank } \\
\text { (1981) }\end{array}$ & $\begin{array}{c}\text { Eastern } \\
\text { Funk I. } \\
\text { Bank } \\
(1979)\end{array}$ & $\begin{array}{c}\text { Southeast } \\
\text { Funk } 1 . \\
\text { Bank } \\
(1980)\end{array}$ & $\begin{array}{c}\text { Western } \\
\text { Funk } 1 . \\
\text { Bank } \\
(1980)\end{array}$ & $\begin{array}{l}\text { Southwest } \\
\text { Funk I. } \\
\text { Bank } \\
(1981)\end{array}$ & $\begin{array}{c}\text { Northern } \\
\text { Grand } \\
\text { Bank } \\
(1980)\end{array}$ \\
\hline Labrador coast ${ }^{2}$ & 35.9 & 35.5 & 16.0 & +4.0 & 19.7 & 5.6 & 2.4 & 1.8 & 0.0 & 0.0 \\
\hline Belle Isle Strait & 6.3 & 15.9 & 10.5 & 5.8 & 7.8 & 2.8 & 2.0 & 2.4 & 2.0 & 2.0 \\
\hline White Bay & 26.4 & 30.1 & 26.8 & 15.9 & 16.1 & 4.5 & 2.2 & 10.0 & 5.9 & 0.0 \\
\hline Notre Dame Bayc & 9.9 & 9.8 & 15.0 & 13.1 & 12.5 & 10.3 & 12.5 & 25.9 & 36.4 & 1.5 \\
\hline Bonavista Bay & 6.8 & 6.1 & 11.0 & 17.4 & 10.9 & 25.6 & 14.5 & 26.6 & 28.2 & 4.4 \\
\hline Trinity Bay & 7.7 & 2.3 & 5.2 & 18.9 & 14.1 & 22.9 & 25.9 & 13.5 & 12.7 & 24.6 \\
\hline Conception Bay & 2.9 & 0.0 & 11.3 & 4.7 & 6.2 & 15.1 & 5.5 & 13.3 & 8.7 & 21.9 \\
\hline Southeast Avalon & 4.1 & 0.3 & 2.7 & 6.5 & 9.1 & 4.7 & 10.8 & 6.0 & 2.1 & 23.3 \\
\hline St. Mary's Bay & 0.0 & 0.0 & 1.5 & 3.6 & 4.1 & 9.1 & 24.2 & 0.7 & 3.8 & 24.3 \\
\hline Tag Recoveries & 146 & 304 & 156 & 206 & 169 & 180 & 93 & 307 & 128 & 52 \\
\hline
\end{tabular}

Unit areas 201, 208 and 209 of Fig. 2.

Unit areas 341 and 342 of Fig. 2.

- Unit areas 339 and 340 of Fig. 2.

to the tagging area, and around Hawke Channel (Fig. 2). It is evident that cod, which were concentrated on the northeastern slope of Hamilton Bank during tagging operations in March 1981, were located farther south along the slope of that bank during the winter of 1982. This indicates that the Hamilton Bank component of the Labrador-East Newfoundland stock complex exhibits some variability in the center of distribution, extending anywhere from the northern to the southern slopes of the bank in different years.

From inshore cod tagging at Domino in southern Labrador and Quirpon in northern Newfoundland during summer in 1962-64 (Templeman, 1979), 60-66\% of the recoveries in the January-May period of subsequent years were made on Hamilton Bank and 17-24\% on Belle Isle Bank, indicative of "homing" from inshore feeding grounds in summer to offshore overwintering areas. Templeman (1979) also showed that cod, which were tagged on northeastern and southeastern Hamilton Bank in April-May, returned mainly to Hamilton Bank in subsequent winters (January-May). Those results, together with these from the present study, show that the cod exhibit well-defined inshoreoffshore migratory patterns typical of homing, with inshore movement for feeding in summer and offshore movement to overwinter and spawn.

\section{Belle Isle Bank (Fig. 3)}

From 2,728 cod tagged on Belle Isle Bank during 26 February-12 March 1978, there were 351 tag recoveries during the five ensuing May-December periods, of which 329 were reported by Newfoundland-Labrador fishermen. The adjusted tag recoveries in coastal waters were distributed from Labrador southward along eastern Newfoundland to the Avalon Peninsula with the highest rates in the region from southern Labrador to White Bay (Fig. 3A). About 90\% of these adjusted recoveries occurred north of Cape Freels (Table 3 ). Although nearly three times as many tags were recovered in the Strait of Belle Isle and southern Labrador areas ( 86 and 83 ) as in the St. Anthony area (31) (Fig. 3B), the adjusted recovery rate for the Strait of Belle Isle was about $35 \%$ of the rate for southern Labrador and $50 \%$ of the rate for the St. Anthony area. The pattern of tag recoveries along the coast indicates clearly that this group of cod, which overwinters on the shelf and slopes of Belle isle Bank, migrates mainly to southern Labrador, Strait of Belle Isle and northeastern Newfoundland as far south as Notre Dame Bay, and confirms Templeman's (1979) results from tagging on Belle Isle Bank in September 1962. There is evidence of migration northward along the Labrador coast in summer, and a few tags were recovered south of Cape Freels. Also, $1 \mathrm{tag}$ was recovered on Flemish Cap, 1 off southwestern Newfoundland and 1 off Cape Breton on the Scotian Shelf.

During the January-April period, tag recoveries were mainly from the tagging site and adjacent areas (Fig. 3) indicating a high degree of homing in 4 successive years to the overwintering areas where they were tagged. There was some evidence of movement of this group of cod northward along the seaward slope of Hamilton Bank. These may be cod which had spawned on the slopes of Hamilton Bank and had migrated to the neighbouring Belle Isle Bank before being tagged there. Movement of these Belle Isle Bank cod southward to the Grand Bank was negligible. During the winter period, single recaptures occurred on Flemish Cap, off Cape Breton on the Scotian Shelf, and off southwestern Nova Scotia.

\section{Northern Funk Island Bank (Fig. 4-6)}

Three tagging experiments were conducted on the northern slope of this bank, which is adjacent to Belle Isle Bank (Fig. 1), during the winters (February-March) of 1978, 1979 and 1981. These experiments involved the tagging of $7,983 \mathrm{cod}$, from which 873 recaptures (714 by Newfoundland-Labrador fishermen) were 


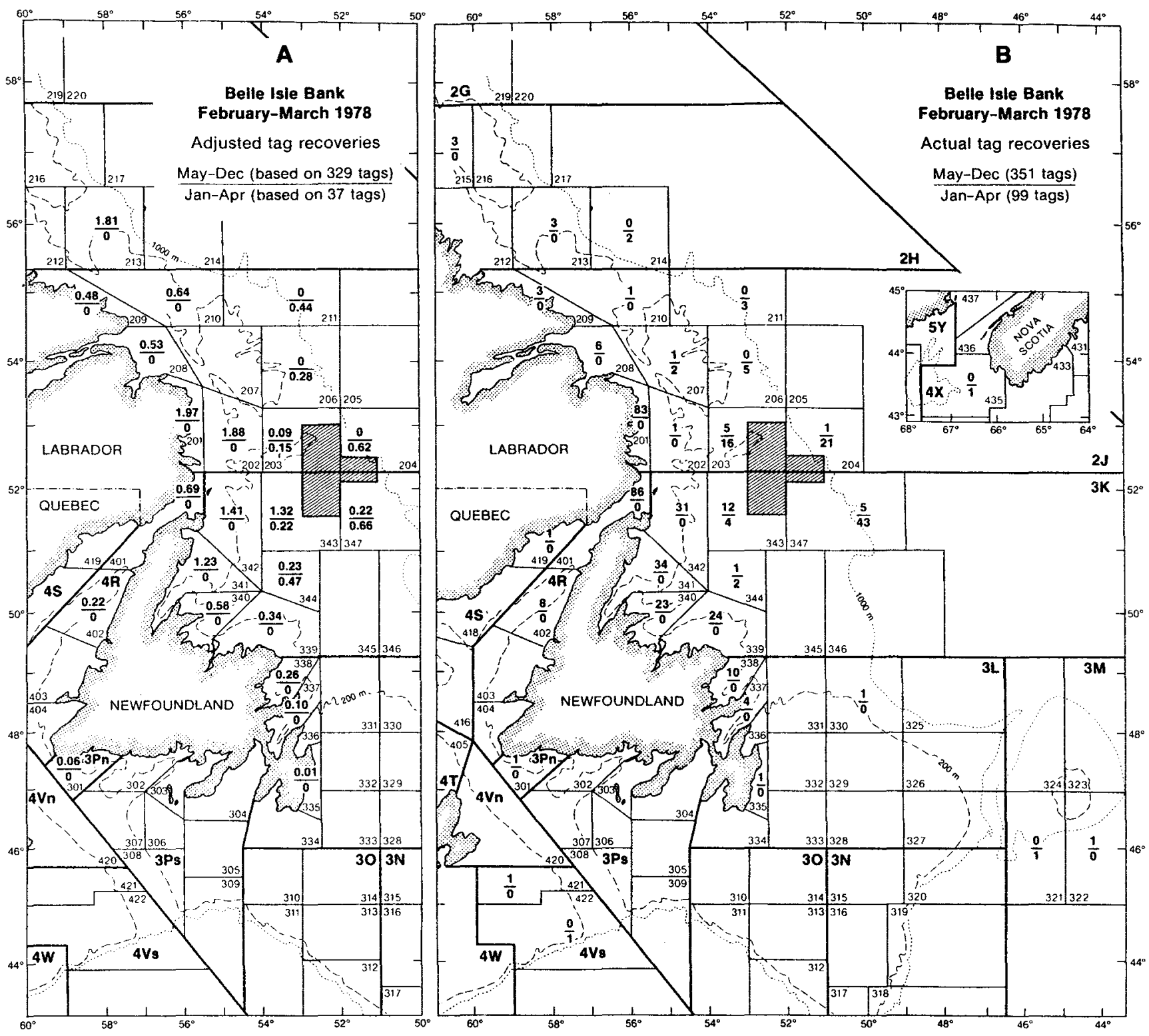

Fig. 3. Distribution of (A) adjusted tag recoveries by Newfoundland-Labrador fishermen and (B) actual tag recoveries by all fishermen, from cod tagged on Belle isle Bank in February-March 1978.

reported during the period from May in the tagging year to December 1982.

From 1,725 cod tagged on the northern slope of Funk Island Bank during 27 February-10 March 1978, there were 181 tag recoveries during the five ensuing May-December periods, of which 168 were reported by Newfoundland-Labrador fishermen (Fig. 4). The inshore recovery rates (adjusted) were highest for the St. Anthony and White Bay areas and about one-third lower for the southern Labrador and Notre Dame Bay areas (Fig. 4A). The recovery rate for the Strait of Belle Isle was about $60 \%$ of the rate for southern Labrador and $40 \%$ of that for the St. Anthony area. From this northern Funk Island Bank tagging, the relative recov- ery rates of tags in the Labrador, Strait of Belle Isle and White Bay areas were consistently lower than those from the Belle Isle Bank tagging experiment (Table 3), particularly so for Labrador coastal waters, and there was greater dispersion of tag recoveries southward to the Avalon Peninsula. Except for the recoveries from the Strait of Belle Isle, the only tags returned from areas outside Div. 2J, $3 \mathrm{~K}$ and $3 \mathrm{~L}$ were 3 from the fishery off central Labrador and single recoveries from Placentia Bay and northeastern Scotian Shelf (Fig. 4B).

From 3,119 cod tagged on the northern slope of Funk Island Bank during 27 February-2 March 1979, there were 248 recoveries in the four ensuing May-December periods, of which 223 were reported by 

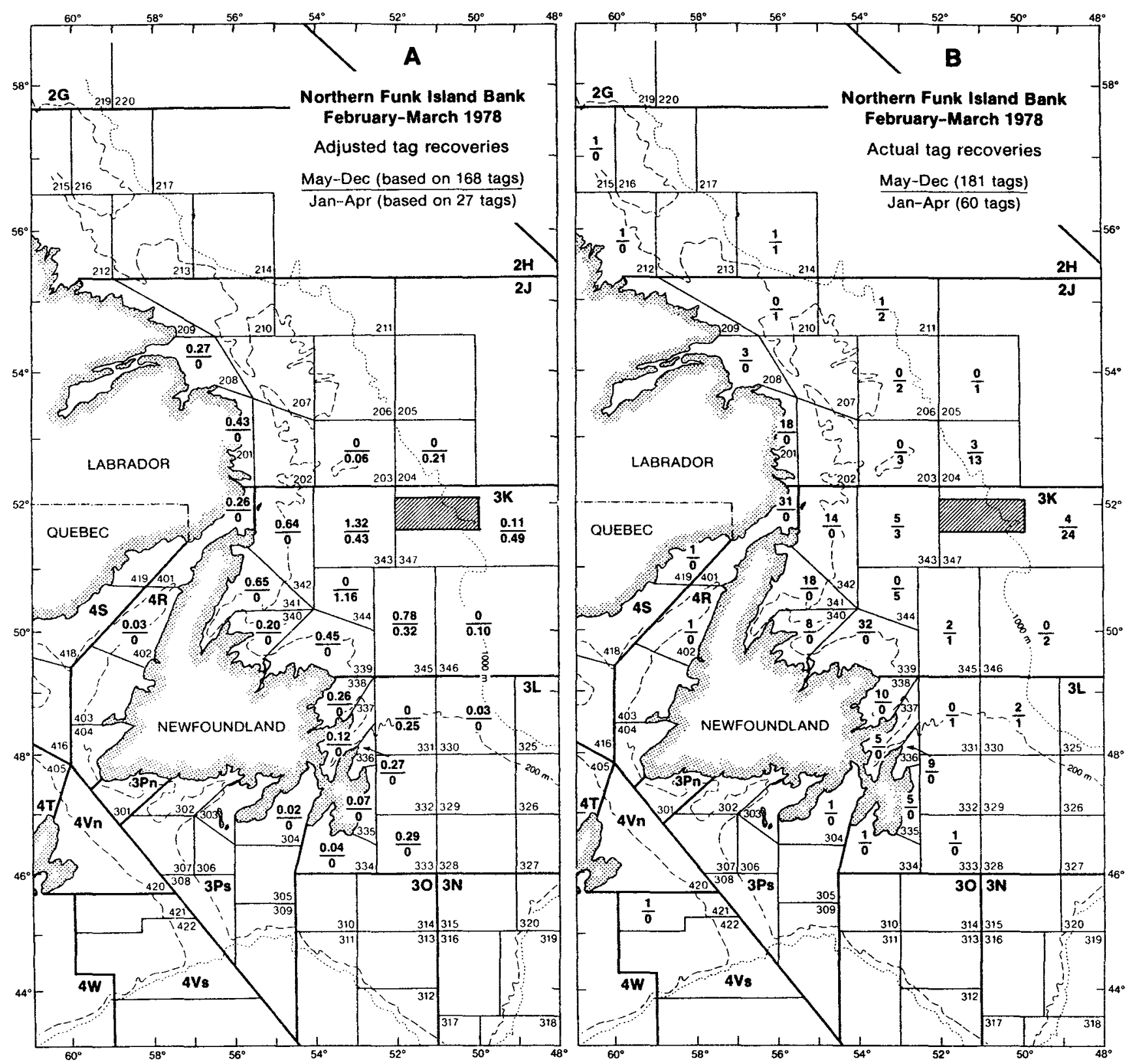

Fig. 4. Distribution of (A) adjusted tag recoveries by Newfoundland-Labrador fishermen and (B) actual tag recoveries by all fishermen, from cod tagged on northern Funk Island Bank in February-March 1978.

Newfoundland-Labrador fishermen (Fig. 5). The adjusted recovery rates were relatively high (0.54-0.79) in coastal areas from southern Labrador to Conception Bay (Fig. 5A). The results from this experiment indicated a more southerly distribution of adjusted tag recoveries than the 1978 tagging (Table 3), with the combined percentages being almost equal for the areas north and south of Cape Freels, compared with a ratio of $68: 32$ for the 1978 tagging in this area and $91: 9$ for the 1978 tagging on Belle Isle Bank. Also, there were substantially fewer recoveries in the Strait of Belle Isle $(6 \%)$ from this northern Funk Island Bank tagging than from the 1978 tagging on Belle Isle Bank
$(16 \%)$. Except for the recoveries in the Strait of Belle Isle, the only tags recovered in areas outside of Div. 2J, $3 \mathrm{~K}$ and $3 \mathrm{~L}$ during May-December were 2 off western Newfoundland, 1 in Placentia Bay and 1 off central Labrador (Fig. 5B).

From 3,139 cod tagged on the northern slope of Funk Island Bank during 25-27 March 1981, there were 216 tag recoveries during the two ensuing May-December periods, of which 193 were reported by Newfoundland-Labrador fishermen (Fig. 6). The highest adjusted recovery rates in coastal waters were for the southern Labrador and St. Anthony areas (1.23-1.60), 

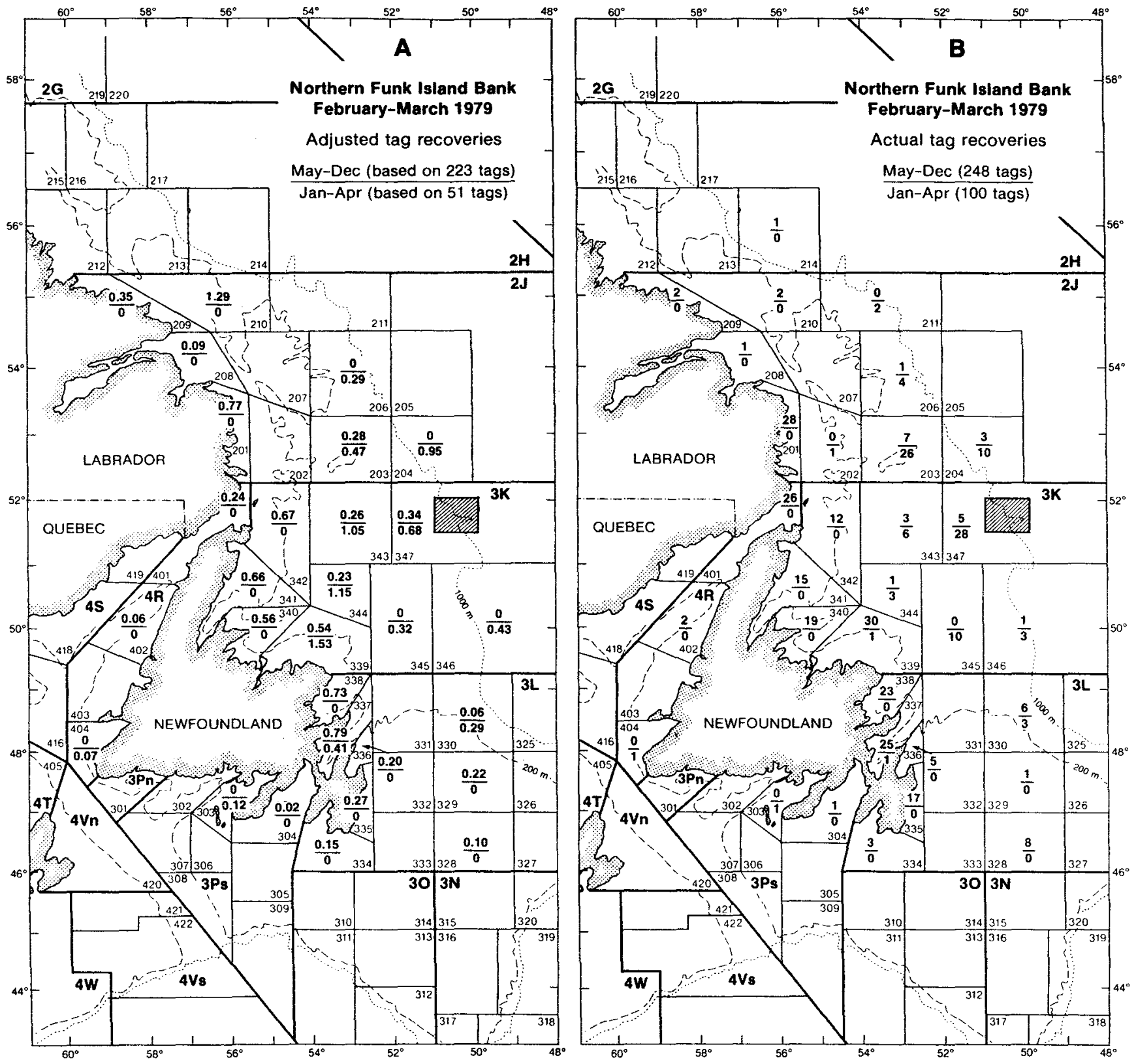

Fig. 5. Distribution of (A) adjusted tag recoveries by Newfoundland-Labrador fishermen and (B) actual tag recoveries by all fishermen, from cod tagged on northern Funk Island Bank in February-March 1979

with somewhat lower values for the eastern Newfoundland areas (0.66-0.85) (Fig. 6A). The rates were quite high in some offshore areas, but these are based on few tag returns and very low catches. The relative proportions of adjusted recoveries from coastal waters were similar to those from the 1979 tagging (Table 3), with slightly more than half $(56 \%)$ from the region north of Cape Freels in 1981, compared with 68\% from the 1978 tagging. The offshore recoveries were mainly on the northern and central areas of the Grand Bank and on the Northeast Newfoundland Shelf (Fig. 6B). Except for those from the Strait of Belle Isle, the only recoveries outside Div. $2 \mathrm{~J}, 3 \mathrm{~K}$ and $3 \mathrm{~L}$ were 2 off central Labrador, 3 in the northern Gulf of St. Lawrence and 1 on the southwestern slope of Grand Bank.
The May-December results from the three taggings on the northern slope of Funk Island Bank confirm that this component of the stock complex contributes substantially to the inshore fishery from southern Labrador southward to the Avalon Peninsula, in contrast to the relatively smaller contributions to the fishery south of Cape Freels from the Hamilton Bank and Belle Isle Bank taggings. These results are similar to those reported by Templeman (1979) from the tagging of $384 \mathrm{cod}$ on northern Funk Island Bank in May 1964.

During the January-April periods in the years after tagging, the recaptures from the 1978, 1979 and 1981 experiments occurred in or near the tagging area and 

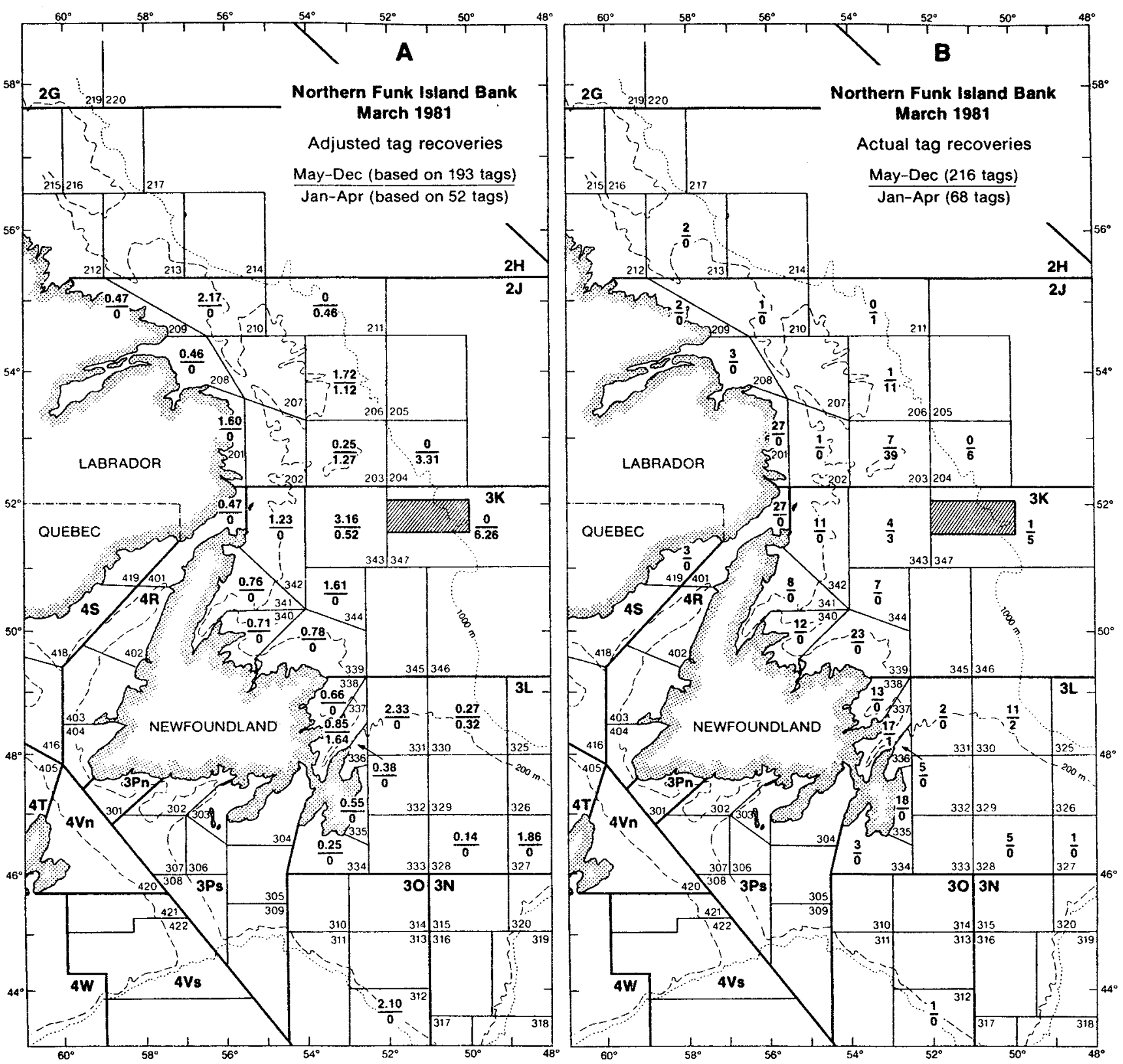

Fig. 6. Distribution of (A) adjusted tag recoveries by Newfoundland-Labrador fishermen and (B) actual tag recoveries by all fishermen, from cod tagged on northern Funk Island Bank in March 1981.

northwestward around Belle Isle Bank and Hamilton Bank. There were a few winter recoveries on the northern Grand Bank from each tagging (Fig. 4B-6B), and single tags were reported from southwestern Newfoundland and Fortune Bay (Fig. 5B).

\section{Eastern and southeastern Funk Island Bank (Fig. 7 and 8)}

From 1,801 cod tagged on the eastern slope of Funk Island Bank during 25 February-2 March 1979 , there were 232 tag recoveries during the four ensuing May-December periods, of which 201 were reported by
Newfoundland-Labrador fishermen. The inshore recoveries were distributed mainly from Notre Dame Bay southward to the Avalon Peninsula, with the highest adjusted rates (1.11 and 1.01) in Bonavista Bay and Trinity Bay (Fig. 7A). The proportion of adjusted recoveries from inshore areas south of Cape Freels $(77 \%)$ was substantially higher than the corresponding proportions $(32-51 \%)$ from the three taggings on the northern slope of Funk Island Bank (Table 3). The relatively high recovery rates in four offshore areas of the Grand Bank (0.63-1.36) are based only on 2 or 3 tag returns from each area (Fig. 7), but there were 11 recoveries in a central Grand Bank area. In addition to 

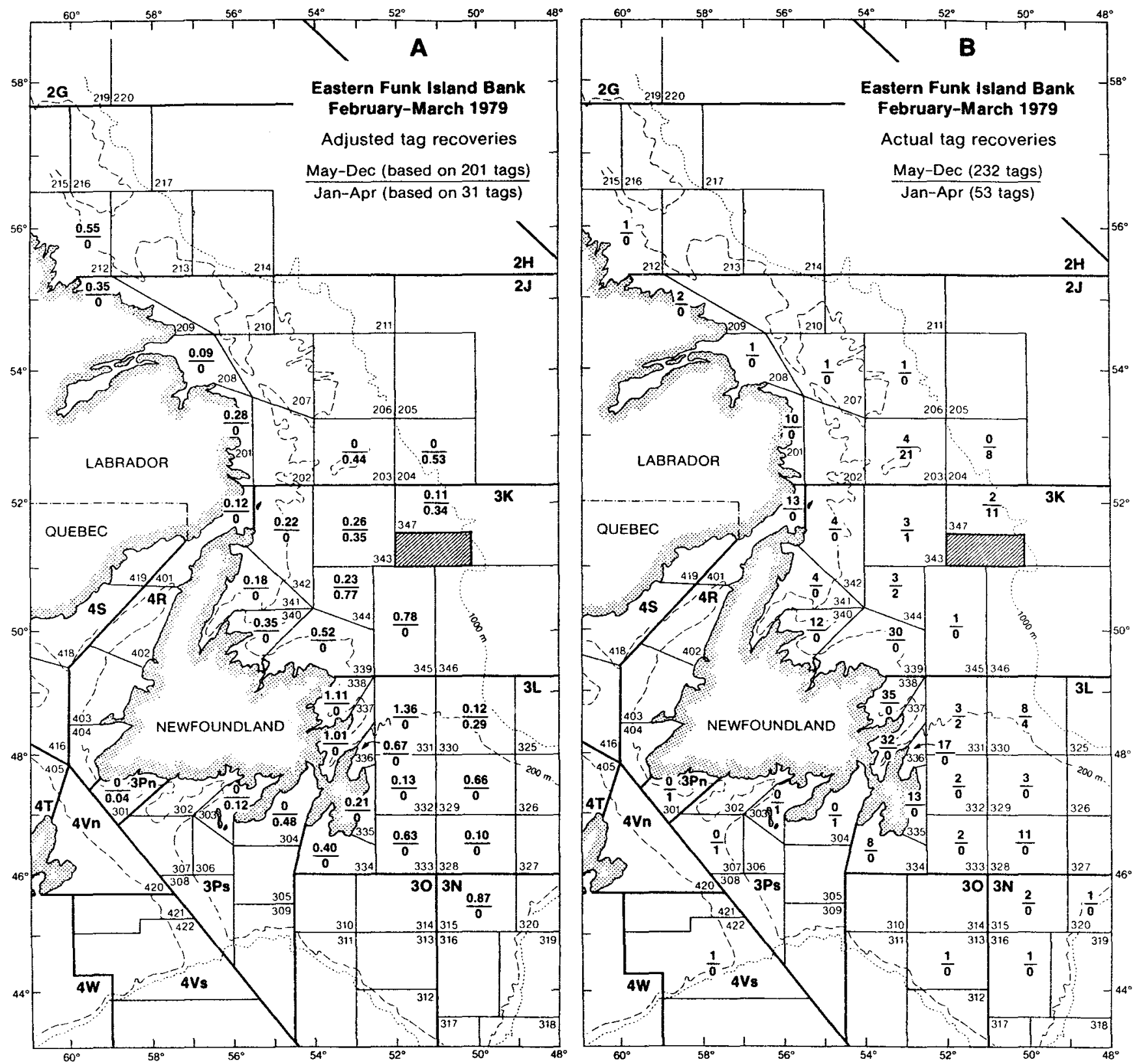

Fig. 7. Distribution of (A) adjusted tag recoveries by Newfoundiand-Labrador fishermen and (B) actual tag recoveries by all fishermen, from cod tagged on eastern Funk Island Bank in February-March 1979.

some movement of cod from the tagging area to southern Labrador and the Strait of Belle Isle in summer, there were 5 recoveries on the southern Grand Bank and 1 on the northeastern Scotian Shelf.

From 2,259 cod tagged on the southeastern slope of Funk Island Bank during 17-23 March 1980, there were 125 tag recoveries in the ensuing three May-December periods, of which 106 were reported by Newfoundland-Labrador fishermen. The distribution of inshore recoveries was generally similar to that of the preceding experiment with some variation in adjusted rates from Notre Dame Bay southward to St.
Mary's Bay (Fig. 8A). The proportion of adjusted recoveries from inshore waters south of Cape Freels was $81 \%$ (Table 3), with substantially higher proportions in the most southerly areas than were evident from the 1979 tagging on the eastern slope of Funk Island Bank. The offshore recaptures occurred mainly around the Virgin Rocks on the central Grand Bank (Fig. 8B). In addition to a few recoveries in the southern Labrador and Strait of Belle Isle areas, there were 2 in the Gulf of St. Lawrence and 2 in Placentia Bay.

In the January-April period, tag recoveries from both experiments were substantially less than those in 

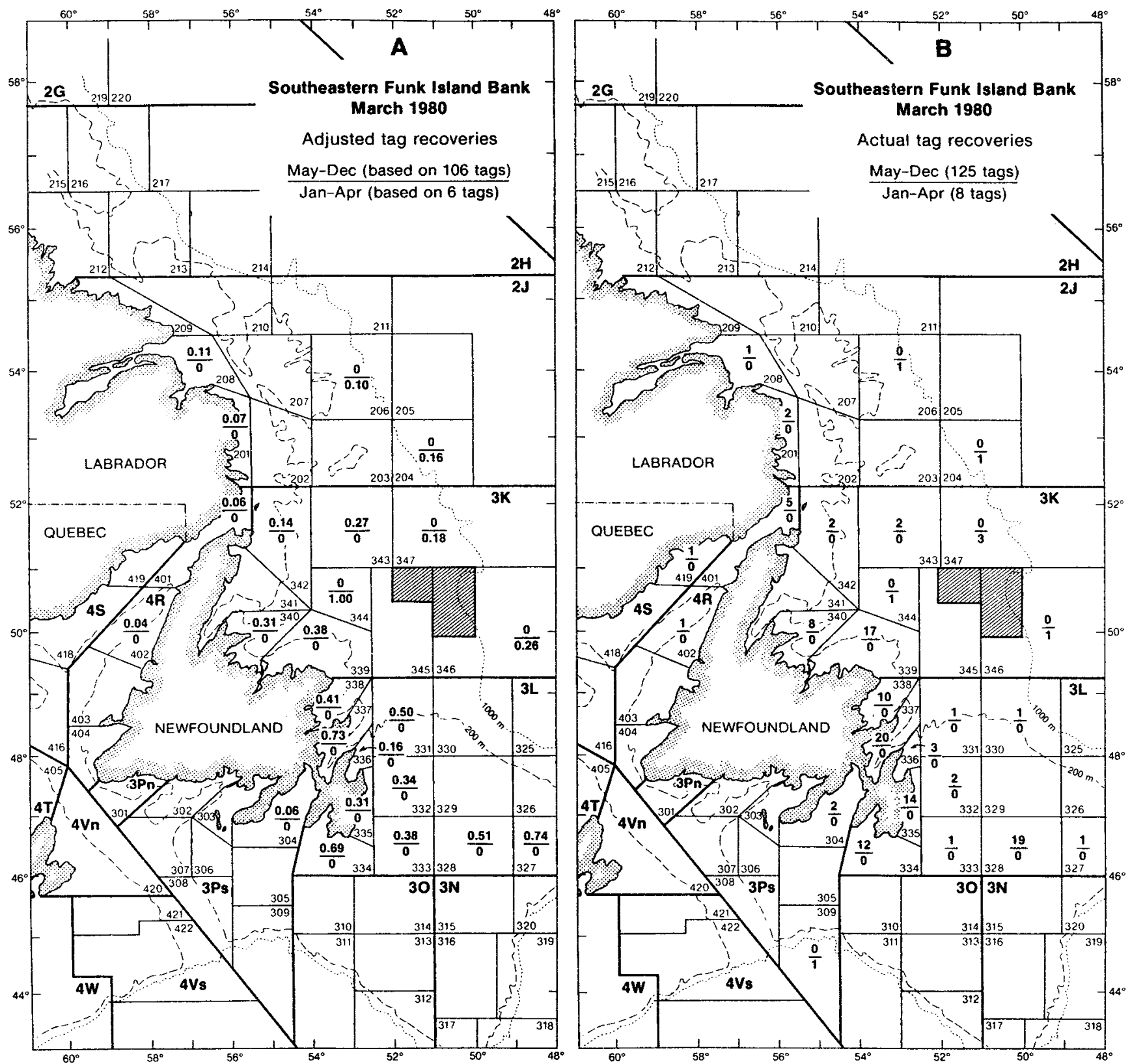

Fig. 8. Distribution of (A) adjusted tag recoveries by Newfoundland-Labrador fishermen and (B) actual tag recoveries by all fishermen, from cod tagged on southeastern Funk Island Bank in March 1980.

the May-December period (Fig. 7 and 8) and were distributed in and around the tagging area and on the northern Grand Bank. Single recoveries were reported from Hamilton Bank in the north and from southern Newfoundland areas in the south.

It is clearly evident from these tagging experiments on Funk Island Bank that migration in summer is mainly to eastern and southeastern Newfoundland from Notre Dame Bay to St. Mary's Bay, with some movement southward to northern and central Grand Bank areas.
Western and southwestern Funk Island Bank (Fig. 9 and 10)

From 2,158 cod tagged on the western slope of Funk Island Bank during 24-27 March 1980, there were 334 tag recoveries during the three ensuing May-December periods, of which 320 were reported by Newfoundland-Labrador fishermen. The inshore recoveries were distributed mainly from the Strait of Belle Isle entrance to the Avalon Peninsula, with the highest adjusted rates (2.43 and 2.06) in Notre Dame Bay and Bonavista Bay (Fig. 9A) and relatively high 


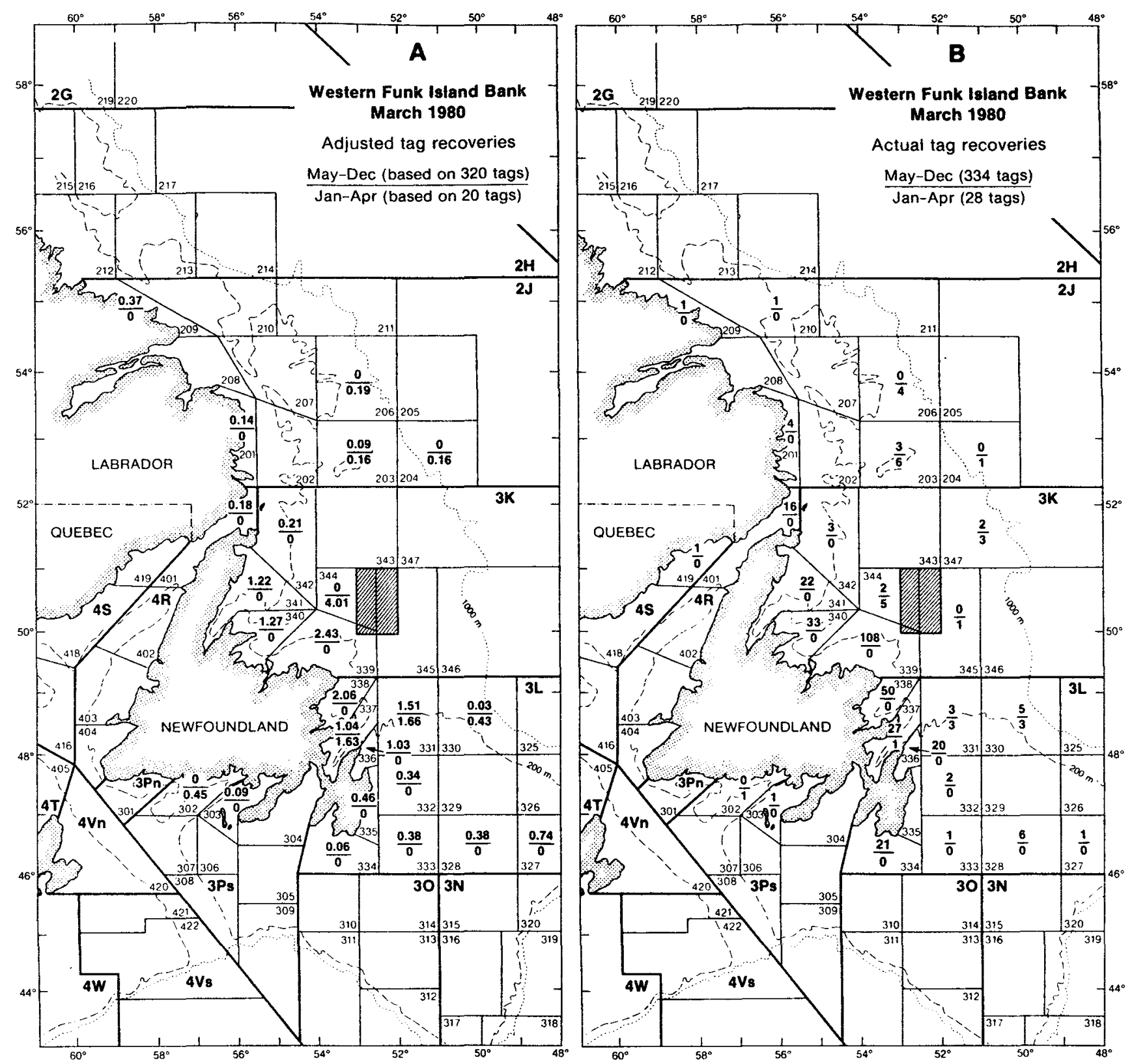

Fig. 9. Distribution of (A) adjusted tag recoveries by Newfoundland-Labrador fishermen and (B) actual tag recoveries by all fishermen, from cod tagged on western Funk Island Bank in March 1980.

rates both northward in the Green Bay and White Bay areas and southward in the Trinity Bay and Conception Bay areas. In contrast to the results from the preceding two experiments on the eastern and southeastern slopes of the bank, there was a substantial increase (to $40 \%$ ) in the percentage of adjusted recoveries from the inshore region north of Cape Freels and a corresponding decrease (to $60 \%$ ) from the southern inshore region (Table 3). There were several offshore recoveries on the northern and central Grand Bank, and single tags were returned from Fortune Bay and the northern Gulf of St. Lawrence (Fig. 9B).
From 1,195 cod tagged on the southwestern slope of Funk Island Bank during 14-17 March 1981, there were 135 tag recoveries during the ensuing two MayDecember periods, of which 134 were reported by Newfoundland-Labrador fishermen. The inshore distribution of adjusted recaptures was approximately similar to that of the preceding experiment, with the highest rates (1.83 and 1.22) in Notre Dame Bay and Bonavista Bay (Fig. 10A) and somewhat lower rates in adjacent areas to the north and south of these bays. The relative proportions of adjusted recoveries north and south of Cape Freels (44 and 56\%) were similar to 

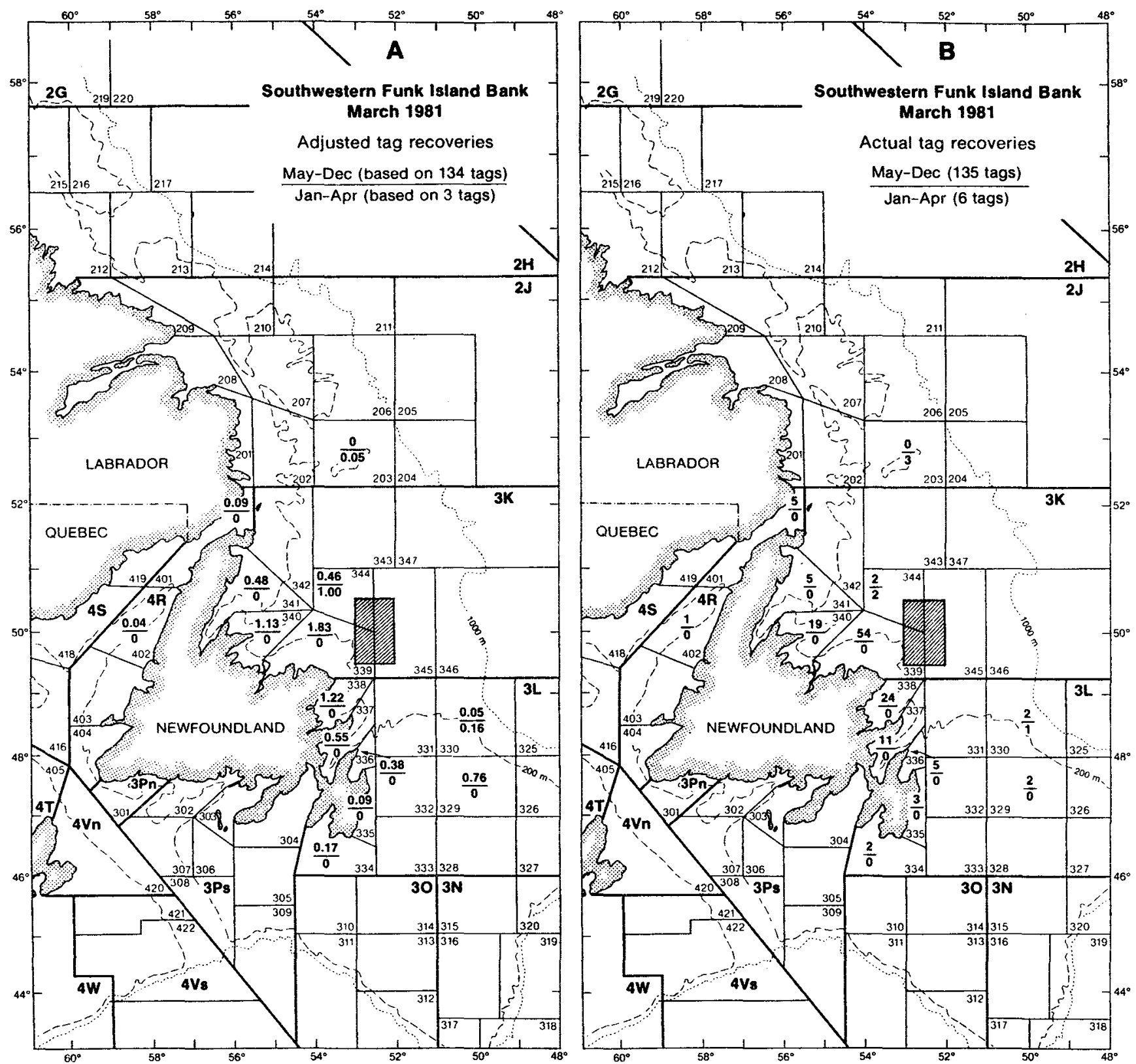

Fig. 10. Distribution of (A) adjusted tag recoveries by Newfoundland-Labrador fishermen and (B) actual tag recoveries by all fishermen, from cod tagged on southwestern Funk Island Bank in March 1981

those for the preceding experiment (Table 3). There were 4 recoveries on the northern Grand Bank and 1 off western Newfoundland, but none were reported from the Labrador coast except in the Strait of Belle Isle (Fig. 10B).

During the January-April period, there were only 28 and 6 tag recoveries from the 1980 and 1981 experiments respectively (Fig. 9 and 10). About half of these recoveries were northward of the tagging site as far as Hamilton Bank, but several occurred in the vicinity of the tagging area and southward on the northern Grand Bank. There were only 2 inshore recoveries, 1 in Trinity Bay and 1 off the south coast of Newfoundland.
Inshore recaptures from these two taggings nearer the coast were somewhat more localized than those from the tagging farther offshore on the northern and eastern slopes of Funk Island Bank. This group of cod contributes to the summer fishery along the coast from the Strait of Belle Isle to the Avalon Peninsula, with greatest concentration in the Notre Dame Bay and Bonavista Bay areas and declining presence in areas north and south of these bays.

\section{Northern Grand Bank (Fig. 11)}

From 1,978 cod tagged on the northern slope of Grand Bank during 10-30 March 1980, there were 134 

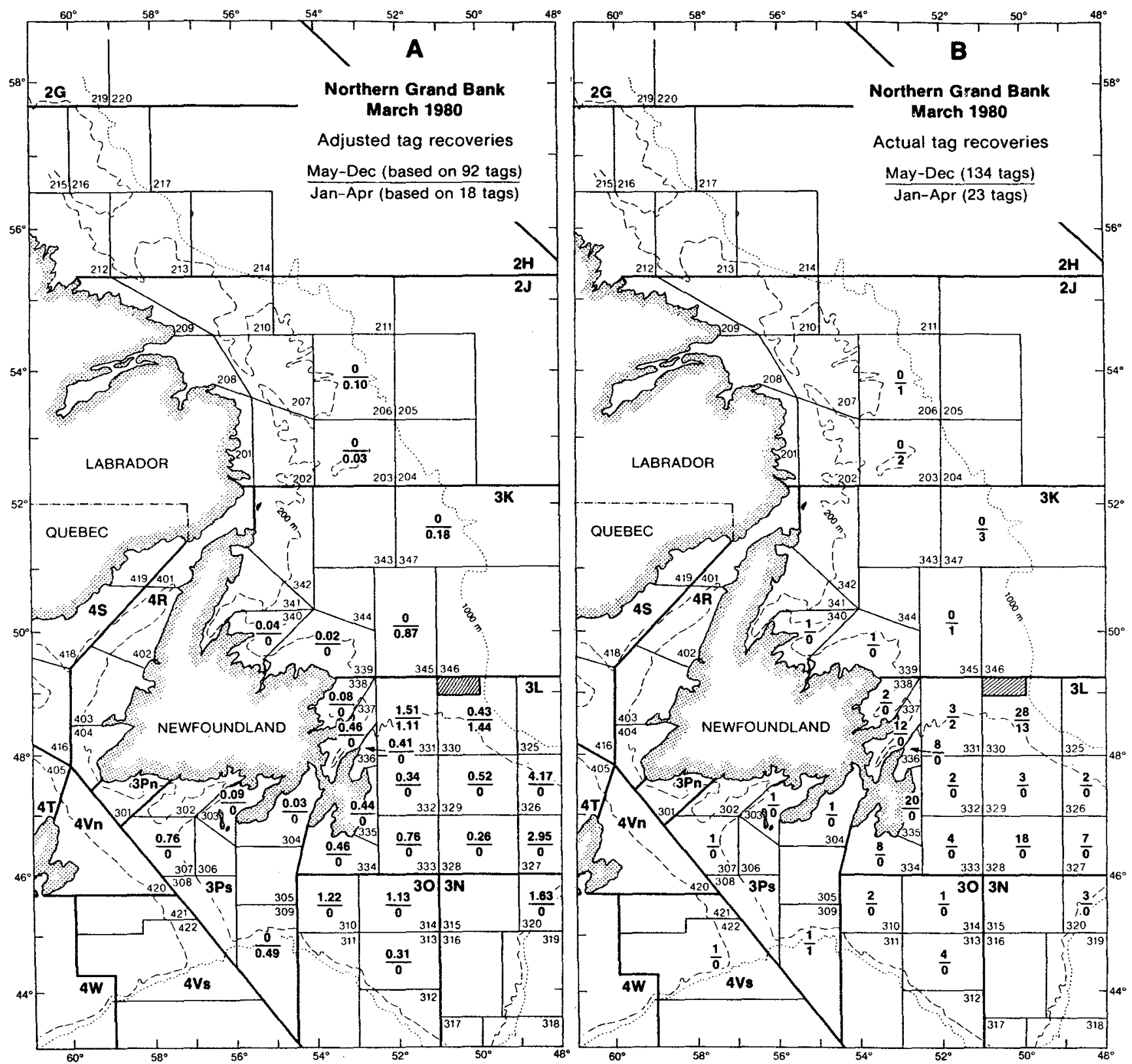

Fig. 11. Distribution of (A) adjusted tag recoveries by Newfoundland-Labrador fishermen and (B) actual tag recoveries by all fishermen, from cod tagged on the northern slope of Grand Bank in March 1980.

tag recoveries during the three ensuing May-December periods, of which 92 were reported by Newfoundland-Labrador fishermen. The inshore recoveries (adjusted) were distributed almost equally (0.41-0.46) in the region from Trinity Bay to St. Mary's Bay (Fig. 11A), with $98.5 \%$ being recovered south of Cape Freels (Table 3). However, most of the recoveries were from offshore areas on the northern half of Grand Bank and a few occurred on the southern part of the bank (Fig. 11B). During the May-December period, there were only 2 recoveries (both inshore) north of Bonavista Bay, and single recoveries were recorded from four unit areas in Div. 3P off southern Newfoundland and 1 from the Scotian Shelf.
Recoveries during the January-April periods of 1981-82 were mainly from areas around the tagging loction, although there was some northward movement to the Northeast Newfoundland Shelf and Hamilton Bank (Fig. 11). There were no recoveries from coastal waters and the southern Grand Bank, but a single tag was recovered on the southern slope of St. Pierre Bank.

\section{Discussion and Conclusions}

The migratory patterns of cod, based on tagging the various spawning components of the stock com- 
plex in Div. $2 \mathrm{~J}, 3 \mathrm{~K}$ and $3 \mathrm{~L}$, confirm that there is associated with each component a definite inshore distribution in summer-autumn and presumably a high degree of homing during winter to concentrate for spawning in or near the offshore areas where the fish were tagged. The components which overwinter on the slopes of Hamilton Bank and Belle Isle Bank contribute very significantly to the summer fishery along the coasts of Labrador and northern Newfoundland, including the Strait of Belle Isle, and insignificantly to the fishery south of Notre Dame Bay. These patterns of migration and summer distribution conform with May's (MS 1966) concept of the "Labrador-Newfoundland" cod stock. High exploitation of the overwintering concentrations in the Hamilton Bank and Belle Isle Bank areas would have adverse effects on the inshore fishery from southern Labrador to Notre Dame Bay. On the other hand, the effects of high exploitation of the concentrations on the northern part of Funk Island Bank would be distributed almost equally over a much larger area from southern Labrador to the Avalon Peninsula.

The stock component which overwinters on the eastern and southeastern slopes of Funk Island Bank contributes very substantially to the inshore fishery of eastern Newfoundland from Notre Dame Bay to St. Mary's Bay, mainly in the region south of Cape Freels. The component which overwinters on the western and southwestern slopes of the bank contributes mainly to the localized fishery in Notre Dame Bay and Bonavista Bay and less significantly to the fishery in areas north and south of these bays. Thus, the components which overwinter and spawn on the slopes of Funk Island Bank collectively form what might best be described as the "Eastern Newfoundland" stock, and the inshore fishery from Notre Dame Bay to the Avalon Peninsula would likely be sensitive to changes in the size of this stock.

The component which overwinters on the northern slope of Grand Bank migrates in summer not only to coastal waters of eastern Newfoundland south of Cape Bonavista but also southward along the eastern edge of Grand Bank, around the Virgin Rocks on the central part of the bank and to the southwestern slope. High exploitation of this stock component in offshore areas would have some effect on the inshore fishery of southeastern Newfoundland.

From all of the cod tagging experiments, there is evidence of substantial inshore migration in summer and subsequent homing to specific offshore overwin- tering and spawning areas, although with some straying. Therefore, heavy offshore exploitation of a particular component of the stock complex in winter could have concomitant adverse effects on the inshore summer fishery. The cod fishery could be poor along a particular section of the coast and successful in other areas, depending on which offshore component of the stock complex was heavily or lightly exploited. It is therefore desirable that the offshore winter fishery be regulated to prevent excessive exploitation of any one component of the stock. This could be achieved by ensuring that the allowable level of fishing effort is distributed over the entire stock complex.

Pinhorn (1984) estimated that about $5 \%$ of the Div. $2 \mathrm{~J}+3 \mathrm{KL}$ stock of cod, which survived the winter fishery in each year of the 1961-74 period, were actually caught in the summer fishery of these years, but that the inshore exploitation increased subsequently to $17 \%$ in 1976 . If these rates reflect the "average" situation, the actual rates of inshore exploitation may vary greatly from area to area, depending on the extent of migration and distribution of the various stock components.

\section{References}

FLEMING, A. M. 1960. Age, growth and sexual maturity of cod (Gadus morhua L.) in the Newfoundland area, 1947-1950. J. Fish. Res. Board Can., 17: 775-809.

ICNAF. 1972. Report of the 22nd Annual Meeting, 25 May-2 June 1974. ICNAF Ann. Proc., 22: 17-66.

MAY, A. W. MS 1966. Biology and fishery of Atlantic cod (Gadus morhua L.) from Labrador. Ph.D. Thesis. McGill Univ., Montreal, $225 p$

1967. Fecundity of Atlantic cod. J. Fish. Res. Board Can., 24: $1531-1551$

MAY, A. W., A. T. PINHORN, R. WELLS, and A. M. FLEMING. 1965. Cod growth and temperature in the Newfoundland area. ICNAF SpeC. Publ., 6: 545-555.

PINHORN, A. T. 1984. Inshore exploitation of Atlantic cod, Gadus morhua, in Labrador and eastern Newfoundland waters. $J$. Northw. Atl. Fish. Sci., 5: 79-84.

TEMPLEMAN, W. 1962. Division of cod stocks in the Northwest Atianic. ICNAF Redbook, 1962(Ill): 79-129.

1966. Marine resources of Newfoundland. Bull Fish. Res. Board Can., 154, $170 \mathrm{p}$.

1974. Migrations and intermingling of Atlantic cod (Gadus morhua) stocks of the Newfoundiand area. J. Fish. Res. Board Can., 31: 1073-1092.

1979. Migrations and intermingling of stocks of Atlantic cod, Gadus morhua, of the Newfoundland and adjacent areas from tagging in 1962-68. ICNAF Res. Bull. 14: 5-50.

1981. Vertebral numbers in Atlantic cod, Gadus morhua, of the Newfoundland and adjacent areas, 1947-71, and their use for delineating cod stocks. J. Northw. Atl. Fish. Sci., 2: 21-45. 


\section{Appendix}

Nominal catches (metric tons) of cod by Newfoundland fishermen in designated fishing areas during January-April and May-December periods of 1978-82. (+ indicates a catch $<0.5$ ton.)

\begin{tabular}{|c|c|c|c|c|c|c|c|c|c|c|c|}
\hline \multirow{2}{*}{$\begin{array}{l}\text { Unit } \\
\text { area }\end{array}$} & \multirow{2}{*}{$\begin{array}{c}\text { ICNAF } \\
\text { Div. }\end{array}$} & \multicolumn{2}{|c|}{1978} & \multicolumn{2}{|c|}{1979} & \multicolumn{2}{|c|}{1980} & \multicolumn{2}{|c|}{1981} & \multicolumn{2}{|c|}{1982} \\
\hline & & Jan-Apr & May-Dec & Jan-Apr & May-Dec & Jan-Apr & May-Dec & Jan-Apr & May-Dec & Jan-Apr & May-Dec \\
\hline 201 & $2 J$ & - & 5,655 & - & 6,826 & - & 12,688 & - & 9,325 & - & 7,544 \\
\hline 202 & $2 J$ & - & 6 & - & 5 & - & - & 147 & - & 946 & 520 \\
\hline 203 & $2 J$ & 1,238 & - & 865 & 9 & - & 6,654 & 9,726 & 224 & 22,104 & 3,791 \\
\hline 204 & $2 J$ & 2,520 & - & 5,002 & 4 & 3,423 & - & 4,572 & - & 1,509 & 40 \\
\hline 205 & $2 \mathrm{~J}$ & - & - & - & 4 & 309 & - & - & - & 188 & - \\
\hline 206 & $2 \mathrm{~J}$ & 199 & - & 58 & 6 & - & 264 & 1,433 & 3 & 8,899 & 577 \\
\hline 207 & $2 J$ & - & 4 & - & 521 & - & 15 & - & 2 & 191 & 67 \\
\hline 208 & $2 J$ & - & 492 & 104 & 1301 & - & 3,044 & - & 2,904 & - & 3,564 \\
\hline 209 & $2 J$ & - & 486 & - & 813 & - & 634 & - & 986 & - & 3,313 \\
\hline 210 & $2 J$ & - & 4 & - & 1,073 & - & 13 & - & 7 & 162 & 454 \\
\hline 211 & $2 \mathrm{~J}$ & - & + & 77 & 9 & - & 17 & - & - & 2,182 & + \\
\hline 212 & $2 \mathrm{H}$ & - & 5 & - & 67 & - & 66 & - & 71 & - & 1,628 \\
\hline 213 & $2 \mathrm{H}$ & - & 16 & - & 14 & - & - & - & 3 & - & 521 \\
\hline 214 & $2 \mathrm{H}$ & - & - & - & 37 & - & - & - & - & - & 431 \\
\hline 215 & $2 \mathrm{H}$ & - & 14 & - & 8 & - & 34 & - & 9 & - & 286 \\
\hline 216 & $2 \mathrm{H}$ & - & + & - & - & - & - & - & - & - & 121 \\
\hline $\begin{array}{l}217- \\
224\end{array}$ & $2 \mathrm{GH}$ & - & - & - & - & - & + & - & 6 & - & 3 \\
\hline 301 & $3 \mathrm{Pn}$ & 460 & 5,811 & 9,896 & 312 & 8,133 & 16 & 3,552 & 7,643 & 10,935 & 3,783 \\
\hline 302 & 3Ps & 77 & 4,573 & 4,426 & 128 & 5,746 & 158 & 549 & 5,561 & 1,667 & 3,103 \\
\hline 303 & $3 \mathrm{Ps}$ & 62 & 3,848 & 5,195 & 626 & 7,207 & 263 & - & 6,632 & 1,354 & 3,820 \\
\hline 304 & $3 P s$ & 34 & 11,310 & - & 13,441 & 1,953 & 12,773 & - & 11,460 & 149 & 11,470 \\
\hline 305 & 3Ps & 9 & 241 & - & 272 & - & 726 & 78 & 1,489 & 31 & 287 \\
\hline 306 & 3Ps & 186 & 4 & 59 & 36 & - & 502 & 9 & 213 & 66 & 49 \\
\hline 307 & 3Ps & 764 & 148 & 1.190 & + & 1,101 & 746 & 2 & 444 & 256 & 129 \\
\hline 308 & 3Ps & 115 & 7 & 242 & 32 & 380 & 515 & 393 & 885 & 74 & 136 \\
\hline 309 & 3Ps & 309 & - & 134 & 13 & - & 166 & 1,041 & - & 1,015 & 383 \\
\hline 310 & 30 & - & 1,042 & - & 2,083 & 7 & 998 & - & 463 & 702 & 180 \\
\hline 311 & 30 & - & 513 & 1,771 & 300 & - & 126 & - & 46 & 388 & 192 \\
\hline 312 & 30 & 139 & 7 & - & 168 & 38 & 15 & - & 40 & 32 & 437 \\
\hline 313 & 30 & - & 316 & - & 91 & - & 107 & - & 1,089 & 112 & 5,198 \\
\hline 314 & 30 & - & 682 & - & 353 & - & 244 & - & 477 & - & 168 \\
\hline 315 & $3 N$ & - & 517 & - & 673 & - & 377 & - & 754 & - & 500 \\
\hline 316 & $3 N$ & - & 250 & - & 603 & 11 & 1.141 & - & 2,564 & - & 934 \\
\hline 317 & $3 N$ & 153 & - & - & 75 & - & 130 & - & 61 & 1 & 42 \\
\hline 318 & $3 N$ & 79 & 1 & - & 251 & - & 428 & 49 & 1 & - & 11 \\
\hline 319 & $3 N$ & 688 & 1 & - & 399 & - & 696 & - & 220 & - & 437 \\
\hline 320 & $3 N$ & 39 & - & - & 217 & - & 256 & - & 103 & 68 & 187 \\
\hline $\begin{array}{l}321- \\
324\end{array}$ & $3 \mathrm{M}$ & 1 & 112 & - & 1 & - & - & - & 2 & - & - \\
\hline 325 & $3 \mathrm{~L}$ & - & 10 & 1 & 147 & 45 & - & 21 & - & 86 & 307 \\
\hline 326 & $3 L$ & - & 116 & 379 & 74 & - & 239 & - & 132 & 52 & 109 \\
\hline 327 & $3 L$ & - & 150 & + & 288 & - & 821 & - & 196 & 一 & 341 \\
\hline 328 & $3 L$ & - & 2,225 & - & 2,034 & - & 851 & - & 3,597 & + & 3,402 \\
\hline 329 & $3 L$ & - & 598 & 7 & 681 & - & 1,218 & - & 1,424 & 14 & 1,207 \\
\hline 330 & $3 L$ & 1,445 & 8 & 5,434 & 256 & - & 10,532 & 632 & 12,781 & 6,310 & 9,659 \\
\hline 331 & $3 L$ & - & 2,219 & 2,231 & 211 & 一 & 1,135 & 1,458 & 172 & 350 & 686 \\
\hline 332 & $3 L$ & - & 441 & - & 2,118 & - & 2,194 & - & 1,416 & 1,684 & 2,248 \\
\hline 333 & $3 L$ & - & 285 & - & 534 & - & 558 & 198 & 1,012 & 10 & 1,050 \\
\hline 334 & $3 L$ & - & 8,924 & 7,092 & 2,442 & 2,804 & 5,342 & - & 5,880 & 29 & 6,254 \\
\hline 335 & $3 L$ & - & 14,827 & - & 17,016 & - & 12,950 & 51 & 14,342 & 34 & 18,309 \\
\hline 336 & $3 L$ & - & 7,541 & 1,310 & 6,018 & - & 6,164 & - & 4,965 & 28 & 8,285 \\
\hline 337 & $3 L$ & 381 & 8,667 & 4,299 & 5,734 & 1,830 & 5,960 & 2 & 7,489 & 611 & 12,434 \\
\hline 338 & $3 L$ & - & 6,261 & - & 7,366 & 3,186 & 4,643 & 3 & 8,875 & 343 & 10,751 \\
\hline 339 & $3 K$ & 156 & 15,052 & - & 11,239 & 413 & 14,986 & 14 & 10,393 & 228 & 19,073 \\
\hline 340 & $3 K$ & - & 5,687 & - & 8,015 & - & 9,127 & - & 6,046 & 31 & 10,762 \\
\hline 341 & $3 K$ & 5 & 5,076 & - & 4,559 & - & 7,503 & - & 3.780 & 22 & 6,748 \\
\hline 342 & $3 K$ & 62 & 4,017 & - & 3,533 & - & 5,421 & - & 2,924 & - & 6,048 \\
\hline 343 & $3 K$ & 1,204 & + & 1,759 & 9 & 137 & 2,825 & 787 & - & 1,931 & 951 \\
\hline 344 & $3 K$ & 1,208 & 3 & 1,682 & 23 & 1,614 & 27 & - & 4,112 & 998 & 236 \\
\hline 345 & $3 K$ & 2,455 & - & 13 & 1,052 & 1,956 & 53 & 1,080 & 16 & 74 & 157 \\
\hline 346 & $3 K$ & 321 & 1 & 2,798 & 10 & 3,210 & - & 1,383 & - & 2,464 & 507 \\
\hline 347 & $3 K$ & 457 & 2 & 12,528 & 99 & 364 & 8,128 & 10,805 & - & 639 & 698 \\
\hline
\end{tabular}


Appendix (continued)

\begin{tabular}{|c|c|c|c|c|c|c|c|c|c|c|c|}
\hline \multirow{2}{*}{$\begin{array}{l}\text { Unit } \\
\text { area }\end{array}$} & \multirow{2}{*}{$\begin{array}{l}\text { ICNAF } \\
\text { Div. }\end{array}$} & \multicolumn{2}{|c|}{1978} & \multicolumn{2}{|c|}{1979} & \multicolumn{2}{|c|}{1980} & \multicolumn{2}{|c|}{1981} & \multicolumn{2}{|c|}{1982} \\
\hline & & Jan-Apr & May-Dec & Jan-Apr & May-Dec & Jan-Apr & May-Dec & Jan-A.pr & May-Dec & Jan-Apr & May-Dec \\
\hline 401 & $4 \mathrm{R}$ & - & 16,454 & - & 18,930 & 297 & 30,285 & - & 26,196 & 32 & 31,114 \\
\hline 402 & $4 \mathrm{R}$ & 696 & 5,521 & 5,087 & 3.728 & 3,380 & 3,540 & 419 & 12,362 & 79 & 11,582 \\
\hline 403 & $4 \mathrm{R}$ & 4,275 & 2,442 & 2,048 & 2,564 & 2,499 & 869 & + & 2,972 & 173 & 2,860 \\
\hline 404 & $4 R$ & 4,930 & 1,058 & 1,517 & 3,222 & 11,018 & 470 & + & 7,500 & 3,546 & 1,894 \\
\hline 405 & $4 T$ & 80 & - & 1,112 & 1,078 & 85 & 26 & 924 & 143 & 3 & 74 \\
\hline 406 & $4 S$ & 225 & 4 & 47 & - & 1,437 & - & 29 & - & 113 & 2 \\
\hline 417 & $4 S$ & - & - & - & - & - & - & - & - & - & - \\
\hline 418 & $4 S$ & - & - & - & - & - & - & - & - & - & 1 \\
\hline 419 & $4 S$ & - & - & - & 一 & - & - & - & 307 & - & 16 \\
\hline 420 & $4 \mathrm{Vn}$ & 3.359 & 2 & - & 1,299 & 1,095 & 558 & 2 & 2,892 & 15,291 & 121 \\
\hline 421 & $4 V_{s}$ & 43 & 65 & - & 90 & - & 902 & 1,107 & - & 1,871 & 22 \\
\hline 422 & $4 V s$ & 89 & 260 & - & 1,273 & 1,736 & 2,863 & 652 & 919 & 1,677 & 1,594 \\
\hline
\end{tabular}


